\title{
End of Inevitability: Programming and Reprogramming
}

\author{
Kursad Turksen
}

Published online: 27 July 2013

(C) Springer Science+Business Media New York 2013

\begin{abstract}
Stem cell commitment and differentiation leading to functional cell types and organs has generally been considered unidirectional and deterministic. Starting first with a landmark study 50 years ago, and now with more recent observations, this paradigm has been challenged, necessitating a rethink of what constitutes both programming and reprogramming processes, and how we can use this new understanding for new approaches to drug discovery and regenerative medicine.
\end{abstract}

Keywords Programming $\cdot$ Reprogramming $\cdot$ Induced pluripotent stem cells $\cdot$ Epigenetic $\cdot$ Differentiation

\section{Introduction}

Through proliferation, cell fate selection and cellular differentiation during embryogenesis, a single cell gives rise to all the cell lineages of the body. Until recently, the processes of fate selection and differentiation were thought to be deterministic and non-reversible. Nuclear transfer experiments done 50 years ago by Gurdon and colleagues showed that the nucleus of differentiated intestinal cells are capable of forming an entire organism [1]. More recently, Yamanaka and colleagues showed that forced expression of a limited number of genes in somatic cells can reverse the committed programmed state to a pluripotent state [2]. The process of reversion from one defined specialized cell type into a pluripotent state is now known as "reprogramming" and the corresponding cells as "induced pluripotent" cells (iPS cells) [3].

K. Turksen $(\bowtie)$

Regenerative Medicine Program, Sprott Centre for Stem Cell

Research, Ottawa Hospital Research Institute,

501 Smyth Road, Ottawa, ON K1H 8L6, Canada

e-mail: kursadturksen@gmail.com
The ability to generate pluripotent cells from adult somatic cells has made them prime candidates for regenerative medicine applications. However, iPS cells generated from people with particular diseases are also being used for disease modeling, drug discovery [4] and potential regenerative treatments [5].

I offer here some comments to frame the individual papers in this special issue, in which the contributors cover different aspects of the programming and reprogramming processes, along with extant challenges and unanswered questions.

Lorenzo et al. [6]. summarize commonly used methodologies and review important aspects/critical points in reprogramming somatic cells into iPS cells. Although the four factors used originally by Yamanaka's group (Oct4, Klf4, Sox2 and c-Myc, otherwise designated OKSM) [2, 7] remain commonly used, there are intense efforts to complement the "Yamanaka factors" with other factors to increase efficiency of the repogramming process, including factors as diverse as, e.g. bcl-xl [8] and E-cadherin [9].

Extensive work on Oct4 has shown that expression of this "master" pluripotency gene is sufficient to induce pluripotency in neural stem cells [10], and the activation of endogenous Oct4 transcription is a key step in the reprogramming of somatic cells into iPS cells [11]. A considerable amount of data suggests that Oct4 is "the gatekeeper into the reprogramming expressway" that can be directed by altering the experimental conditions [12].. Considering the importance of this, Ryan et al. [13]. have suggested the need for very strict criteria and methodology to evaluate the expression of Oct 4 in different stages and cell types.

The many diverse adult tissue sources/cell types being used to generate iPS cells, including e.g., prostatic epithelial cell [14], ciliary body epithelial cells [15], and human hair follicular mesenchymal stem cells [16]. While these and other studies provide strong support for the view that most cell types are reprogrammable, it is clear that the process is very inefficient and conditions vary from cell type to cell type. Interestingly, for example, human epidermal cells appear to reprogram with much higher efficiency than many other 
cell types; at least 100-fold more efficient and two-fold faster than reprogramming of adult human fibroblasts [17]. It remains to be determined whether certain somatic cells type[s] have a greater propensity for more efficient and robust reprogramming and what the underlying mechanisms are.

What role epigenetic modifications play in reprogramming, and how that may contribute to differences between cell types and ages of donor tissue is now beginning to be explored. Not only programming but reprogramming of cells is accompanied by drastic changes in the epigenetic profiles of the cells [18, 19].. To achieve a comprehensive understanding of programming and reprogramming, it will be essential to understand the mechanisms that regulate the epigenome and transcriptome in cells [20]. The embryonic stem (ES) cell system has been used to look at lineage specific programming processes in the context of histone modification. For example, histone codes employed by the $\beta$ globin locus have been found to be conserved throughout erythroblast development [21]. On the reprogramming front, it has become evident that an epigenetic barrier protects the identity of somatic cells, and that these cells acquire pluripotency by breaking the epigenetic barrier by reprogramming factors such as Oct3/4, Sox2, Klf4, Myc and LIN28 [18]. However, it remains unknown how forced expression of these factors leads to the multitude of epigenetic changes observed during the reprogramming process.

Using a high-resolution single nucleotide polymorphism array, Hussein et al. [22]. compared copy number variations of different passages of human iPS cells with their fibroblast cell origins and with human ES cells. They showed that significantly higher copy number variations were present in the early-passage human iPS cells than intermediate passage human iPS cells, fibroblasts or human ES cells. Expansion of the iPS cells in culture selected against mutated cells, driving the lines towards a genetic state resembling human ES cells. In another very interesting study, it was observed that the reprogramming process disrupts the regulation of mitochondrial DNA replication, but this can be re-established through the use of epigenetic modifiers [23].

Understanding the biological mechanisms essential for successful iPS cell generation requires both accurate capture of cells undergoing the reprogramming process and identification of the associated global gene expression changes. However, the low efficiency and resulting heterogeneity using most methods for generation of iPS cells have hindered understanding of the molecular mechanisms promoting, and roadblocks preventing, efficient reprogramming. Although several intermediate populations have been described, it has proved difficult to characterize low frequency intermediate stages from the truly pluripotent iPS cell state. Thus, uncovering molecular markers delineating stages of the reprogramming process are of considerable interest. One such gene is undifferentiated transcription factor 1 (UTF1), a target of Oct 4 and Sox 2 and a bivalent chromatin component. UTF1 is involved in ES cell-specific chromatin organization, and its expression pattern during cell reprogramming and subsequent differentiation appears to be tightly connected with the pluripotent stem cell state [24]. A second example is the high mobility group AT-hook 2 (HMGA2) protein, a non-histone chromatin factor normally expressed in ES cells and during early developmental stages, and known to have a critical role in maintenance of pluripotency [25]. The hope is that such markers can be used in the isolation and characterization of cells in distinct differentiation stages [26]. Recently, it was reported that in mouse embryonic fibroblasts, reprogramming follows an orderly sequence of transitions, marked by changes in the cell-surface markers CD44 and ICAM1. These markers together with a Nanog-enhanced green fluorescent protein reporter, prompted the authors to conclude that reprogramming is not simply the reversal of the normal developmental processes [27].

Precise, robust and scalable directed differentiation of pluripotent stem cells, whether iPS or ES cells, is an important goal with respect to disease modeling, drug development and regenerative medicine applications [28]. Amongst lineages of intense interest are the neuronal lineages. Using the AggreWell ${ }^{\mathrm{TM}} 400$ system, Kozhich et al. standardized the differentiation of human ES and iPS cells to a neuronal fate using defined conditions [29]. Protocols for the differentiation of iPS cells into functional dopaminergic neurons [30], motor neurons [31], and medium spiny neurons [32] has been reported. Differentiation into hematopoeitic cells [33], hepatocyte-like cells [34], and pancreatic cells [35] have also been reported.

Taken together, the papers in this special issue together with the ongoing studies in the field of programming and reprogramming underscore both the exciting advances and the significant challenges remaining to fully realize the potential of iPS cells.

Acknowledgments A very special thank you goes to Dr. Jane Aubin for critical reading of this commentary. I thank Dr. Andras Nagy and members of Nagy lab for stimulating discussions.

\section{References}

1. Gurdon, J. B. (1962). Developmental capacity of nuclei taken from intestinal epithelium cells of feeding tadpoles. Journal of Embryology \& Experimental Morphology, 10, 622-640.

2. Takahashi, K., \& Yamanaka, S. (2006). Induction of pluripotent stem cells from mouse embryonic and adult fibroblast cultures by defined factors. Cell, 126(4), 663-676. Pub 2006 Aug 10. PubMed PMID: 16904174.

3. Takahashi, K., \& Yamanaka, S. (2013). Induced pluripotent stem cells in medicine and biology. Development, 140(12), 2457-2461. doi:10.1242/dev.092551. PubMed PMID: 23715538.

4. Pan-Montojo, F., \& Funk, R. H. (2012). Implications of Parkinson's disease pathophysiology for the development of cell replacement strategies and drug discovery in neurodegenerative diseases. CNS \& Neurological Disorders Drug Targets, 11(7), 907-920. PubMed PMID: 23131153. 
5. Lomax, G. P., \& Shepard, K. A. (2013). Return of results in translational iPS cell research: considerations for donor informed consent. Stem Cell Research and Therapy, 4(1), 6. [Epub ahead of print] PubMed PMID: 23336317.

6. Lorenzo, I. M., Fleischer, A., Bachiller, D. (2012). Generation of mouse and human induced pluripotent stem cells (iPSC) from primary somatic cells. Stem Cell Reviews.

7. Takahashi, K., Tanabe, K., Ohnuki, M., Narita, M., Ichisaka, T., Tomoda, K., \& Yamanaka, S. (2007). Induction of pluripotent stem cells from adult human fibroblasts by defined factors. Cell, 131(5), 861-872. PubMed PMID: 18035408.

8. Su, R. J., Baylink, D. J., Neises, A., Kiroyan, J. B., Meng, X., Payne, K. J., Tschudy-Seney, B., Duan, Y., Appleby, N., KearnsJonker, M., Gridley, D. S., Wang, J., Lau, K. H., \& Zhang, X. B. (2013). Efficient generation of integration-free iPS cells from human adult peripheral blood using BCL-XL together with Yamanaka factors. PLoS One, 8(5), e64496. PubMed PMID: 23704989.

9. Redmer, T., Diecke, S., Grigoryan, T., Quiroga-Negreira, A., Birchmeier, W., \& Besser, D. (2011). E-cadherin is crucial for embryonic stem cell pluripotency and can replace OCT4 during somatic cell reprogramming. EMBO Reports, 12(7), 720-726. doi:10.1038/embor.2011.88. PubMed PMID: 21617704; PubMed Central PMCID: PMC3128971.

10. Kim, J. B., Greber, B., Araúzo-Bravo, M. J., Meyer, J., Park, K. I., Zaehres, H., \& Schöler, H. R. (2009). Direct reprogramming of human neural stem cells by OCT4. Nature, 461(7264), 649-653. doi:10.1038/nature08436.

11. Greder, L. V., Gupta, S., Li, S., Abedin, M. J., Sajini, A., Segal, Y., Slack, J. M., \& Dutton, J. R. (2012). Analysis of endogenous Oct4 activation during induced pluripotent stem cell reprogramming using an inducible Oct4 lineage label. Stem Cells, 30(11), 25962601. doi:10.1002/stem.1216.

12. Sterneckert, J., Höing, S., \& Schöler, H. R. (2012). Concise review: Oct4 and more: the reprogramming expressway. Stem Cells, 30(1), 15-21. doi:10.1002/stem.765.

13. Ryan, J. M., Pettit, A. R., Guillot, P. V., Chan, J. K., Fisk, N. M. (2011). Unravelling the pluripotency paradox in fetal and placental mesenchymal stem cells: Oct-4 expression and the case of the emperor's new clothes. Stem Cell Reviews. Dec 11. [Epub ahead of print].

14. Zhao, H., Sun, N., Young, S. R., Nolley, R., Santos, J., Wu, J. C., \& Peehl, D. M. (2013). Inducedpluripotency of human prostatic epithelial cells. PLoS One, 8(5), e64503. Print 2013. PubMed PMID:23717621; PubMed Central PMCID: PMC3661502.

15. Ni, A., Wu, M. J., Nakanishi, Y., Chavala, S. H. (2013). Facile and efficient reprogramming of ciliary body epithelial cells into induced pluripotent stem cells. Stem Cells and Development, Jun 5. [Epub ahead of print] PubMed PMID: 23635313.

16. Wang, Y., Liu, J., Tan, X., Li, G., Ago, Y., Liu, X., Zhang, L., Li, Y. (2012). Induced pluripotent stem cells from human hair follicle mesenchymal stem cells. Stem Cell Reviews, Dec 16. [Pub ahead of print]

17. Aasen, T., Raya, A., Barrero, M. J., Garreta, E., Consiglio, A., Gonzalez, F., Vassena, R., Bilić, J., Pekarik, V., Tiscornia, G., Edel, M., Boué, S., \& Izpisúa Belmonte, J. C. (2008). Efficient and rapid generation of induced pluripotent stem cells from human keratinocytes. Nature Biotechnology, 26(11), 1276-1284. doi:10.1038/nbt.1503. Epub 2008 Oct 17.

18. Watanabe, A., Yamada, Y., \& Yamanaka, S. (2013). Epigenetic regulation in pluripotent stem cells: a key to breaking the epigenetic barrier. Philosophical Transactions of the Royal Society of London. Series B, Biological Sciences, 368(1609), 20120292. 10.1098/ rstb.2012.0292.

19. Flöttmann, M., Scharp, T., \& Klipp, E. (2012). A stochastic model of epigenetic dynamics in somatic cell reprogramming. Frontiers in Physiology, 3, 216. doi:10.3389/fphys.2012.00216. Epub Jun 27. PubMed PMID: 22754535; PubMed Central PMCID: PMC3384084.

20. Telese, F., Gamliel, A., Skowronska-Krawczyk, D., GarciaBassets, I., \& Rosenfeld, M. G. (2013). "Seq-ing" insights into the epigenetic of neuronal gene regulation. Neuron, 77(4), 606623. doi:10.1016/j.neuron.2013.01.034.

21. Chang, K. H., Fang, X., Wang, H., Huang, A., Cao, H., Yang, Y., Bonig, H., Stamatoyannopoulos, J. A., Papayannopoulou, T. (2012). Epigenetic modifications and chromosome conformations of the beta globin locus throughout development. Stem Cell Reviews, Feb 29. [Epub ahead of print].

22. Hussein, S. M., Batada, N. N., Vuoristo, S., Ching, R. W., Autio, R., Närvä, E., Ng, S., Sourour, M., Hämäläinen, R., Olsson, C., Lundin, K., Mikkola, M., Trokovic, R., Peitz, M., Brüstle, O., Bazett-Jones, D. P., Alitalo, K., Lahesmaa, R., Nagy, A., \& Otonkoski, T. (2011). Copy number variation and selection during reprogramming to pluripotency. Nature, 471(7336), 58-62. doi:10.1038/nature09871.

23. Kelly, R. D., Sumer, H., McKenzie, M., Facucho-Oliveira, J., Trounce, I. A., Verma, P. J., \& St John, J. C. (2013). The effects of nuclear reprogramming on mitochondrial DNA replication. Stem Cell Reviews, 9(1), 1-15. doi:10.1007/s12015-011-9318-7.

24. Morshedi, A., Soroush Noghabi, M., Dröge, P. (2011). Genetic control elements as iPSC reporter. Stem Cell Reviews, Dec 28. [Epub ahead of print].

25. Morshedi, A., Ren, Z., Li, J. (2012). Dröge P probing into the biological processes influenced by ESC factor and oncoprotein HMGA2 using iPSCs. Stem Cell Reviews, May 1 [Epub ahead of print].

26. van Laake, L. W., Qian, L., Cheng, P., Huang, Y., Hsiao, E. C., Conklin, B. R., \& Srivastava, D. (2010). Reporter-based isolation of induced pluripotent stem cell- and embryonic stem cell-derived cardiac progenitors reveals limited gene expression variance. Circulation Research, 107(3), 340-347. doi:10.1161/CIRCRESAHA. 109.215434. Epub 2010 Jun 17. PubMed PMID: 20558827; PubMed Central PMCID: PMC2919280.

27. O’Malley, J., Skylaki, S., Iwabuchi, K. A., Chantzoura, E., Ruetz, T., Johnsson, A., Tomlinson, S. R., Linnarsson, S., \& Kaji, K. (2013). Highresolution analysis with novel cell-surface markers identifies routes to iPS cells. Nature. doi:10.1038/nature12243. Epub ahead of print.

28. Mackay-Sim, A. (2013). Patient-derived stem cells: pathways to drug discovery for brain diseases. Frontiers in Cellular Neuroscience, 7 29. doi:10.3389/fncel.2013.00029. Epub 2013 Mar 27. PubMed PMID: 23543597; PubMed Central PMCID: PMC3608922.

29. Kozhich, O. A., Hamilton, R. S., Mallon, B. S. (2012). Standardized generation and differentiation of neural precursor cells from human pluripotent stem cells. Stem Cell Reviews, Mar 3. [Epub ahead of print].

30. Roessler, R., Boddeke, E., Copray, S. (2012). Induced pluripotent stem cell technology and direct conversion: new possibilities to study and treat parkinson's disease. Stem Cell Reviews. Apr 13. [Epub ahead of print].

31. Stockmann, M., Linta, L., Föhr, K. J., Boeckers, A., Ludolph, A. C., Kuh, G. F., Udvardi, P. T., Proepper, C., Storch, A., Kleger, A., Liebau, S., Boeckers, T. M. (2011). Developmental and functional nature of human iPSC derived motoneurons. Stem Cell Reviews, Nov 3. [Epub ahead of print].

32. Delli Carri, A., Onorati, M., Castiglioni, V., Faedo, A., Camnasio, S., Toselli, M., Biella, G., Cattaneo, E. (2013). Human pluripotent stem cell differentiation into authentic striatal projection neurons. Stem Cell Reviews, Apr 27. [Epub ahead of print] PMID: 23625190 PubMed - as supplied by publisher.

33. Inoue-Yokoo, T., Tani, K., Sugiyama, D. (2012). Mesodermal and hematopoietic differentiation from ES and iPS Cells. Stem Cell Reviews, Jun 9. [Epub ahead of print].

34. Asgari, S., Moslem, M., Bagheri-Lankarani, K., Pournasr, B., Miryounesi, M., Baharvand, H. (2011). Differentiation and transplantation of human induced pluripotent stem cell-derived hepatocytelike cells. Stem Cell Reviews. Nov 11. [Epub ahead of print].

35. Sui, L., Geens, M., Sermon, K., Bouwens, L., Mfopou, J. K. (2013). Role of BMP signaling in pancreatic progenitor differentiation from human embryonic stem cells. Stem Cell Reviews, Mar 7. [Epub ahead of print]. 